\title{
Unblocking a Free Market Perspective in Labor Economics
}

\author{
Per Bylund \\ University of Missouri \\ Per.Bylund@mizzou.edu
}

\section{Introduction}

In Labor Economics from a Free Market Perspective: Employing the Unemployable (2008) Walter Block presents a seemingly comprehensive free market perspective on the economics of the labor market. From this perspective Block discusses the economics of wage determination and the minimum wage's effects on the labor market; the economic impact of labor unions and unionized regulation as well as the economics of unemployment insurance and academic tenure; and he touches on immigration, redistributive justice, and slavery reparations. There should be no surprise that the free market perspective allows Block to argue that regulation and intervention in the market cause imbalances and disequilibria and are therefore economically inefficient and undesireable. But Block goes one step further and argues that all kinds of regulation or tampering with a free market setting for voluntary interaction of individuals are simply wrong. There is no doubt that Labor Economics from a Free Market Perspective is a very provocative book.

On the one hand, it is a treatise on labor economics covering basic economic truths such as the determination of wages and the effects in the labor market of enforced minimum wage laws and unionism. Just like in Block's 1976 book Defending the Undefendable, from which the sub title "Employing the Unemployable" seems to be borrowed, the author investigates well-known institutions and offers thought-provoking arguments based on distinctly economic reasoning. The difference is that Block does not pick heavily disliked social phenomena to which he offers strong arguments in favor, which is the case in Defending the Undefendable, but argues fiercely against generally accepted and commonly advocated political solutions to perceived market problems. Even though many of the arguments are true from a mainstream economics point of view, most of the illustrative examples and analogies to complement them are, in a typically Blockian manner, very outspoken, shocking, and - sometimes - even infuriating. 
On the other hand, Labor Economics from a Free Market Perspective is far from a neutral and wertfrei theoretical study of economic phenomena accompanied by solutions based on pure economic reasoning. It is a treatise with a distinct ideological base: it is hard-core libertarian, a view that, in its intrepid advocacy for unbridled individual liberty, itself should prove provocative to most people. This radical perspective literally permeates the book's chapters and, combined with Block's obvious fancy for taking coattrailing standpoints, it leaves no reader unperturbed.

The author does not try to hide the fact that the book takes a clear valuebased position. Contrarily, in the introduction Block explicitly states that it is "an ideological book" but that this, to the author, does not mean the approach is unscientific but only that it "takes a position on ideas" (p. xix). The position is explicit already in the title of the book and is further stressed in the introduction, where the author declares that the book "look[s] at numerous labor market issues from a vantage point of free enterprise or libertarianism" and that a "cure" to the problems discussed is available through "private property rights, the non-aggression principle and the law of free association" (p. xix).

An opponent to libertarianism and free markets would, as would economists and other representatives for the "positive sciences," find plenty of reasons to criticize Block. It is safe to say that the bulk of such criticism would target the ideologically based perspective the author has chosen, and that such critique would be based on the seemingly obvious contradiction between science and ideology. In this paper, however, I will argue that the "obvious" contradiction need not be contradictory at all. From a radically libertarian point of view it can be argued that the "is-ought problem" is partially solved, or at least inapplicable, and therefore that criticism based on "Hume"s Law" may be misdirected. This is not to say, however, that Block cannot be criticized for the assumed ideological perspective on which his economic arguments are supposedly based.

In the remainder of this paper, I continue to analyze the essence of Block's argument from what $I$ suspect is a somewhat unexpected angle: I criticize the scope of his arguments, and especially his conclusions and underlying assumptions and reasons, adopting the radically libertarian or free-market point of view - the very same view championed and utilized by Block.

\section{Hume's Law and the Libertarian Idea}

David Hume (1739-1740) famously identified that there is a significant and important difference between descriptive ("is") and prescriptive ("ought") 
statements. He advised against deriving an "ought" from an "is," i.e., to draw normative conclusions based on empirical facts, without clearly explaining exactly how employed ought-statements follow from isstatements. Hume is often assigned the position that there is no solution to the "is-ought problem," and this so-called Hume's Law (that "ought" cannot be derived from "is") is often used to clearly distinguish between and separate positive (empirical) science from normative (ethics).

Block"s "ideological book" seems to clearly violate Hume's Law in that it argues from a point of view of libertarianism (i.e., libertarian ethics) using primarily arguments from a distinctly positive science, namely economics. As has already been noted, however, this may not necessarily be a correct interpretation of Block's position and arguments. There are two reasons for this: firstly, Block is an economist in the Austrian tradition (see e.g. Block, 1999), which means he bases the argument on praxeological reasoning (Mises, 1949; Rothbard, 1962) rather than "mainstream" economic techniques; and secondly, libertarianism as an ideology is often portrayed as an open-ended and tolerant "system" that sets a non-restrictive formal framework but refuses to provide a social blueprint, which makes it less normative than most ideologies. As we shall see, free markets and libertarianism may not be different in substance or nature but only in approach or perspective.

The free market is the starting point in economic analysis and very often the "ideal" in terms of market efficiency. Market equilibrium theory, which is a cornerstone in mainstream economic analysis, shows maximum resource utilization in terms of production (supply) and, as a consequence, satisfaction of consumer wants (demand). In other words, economic theory strives to find the most efficient means to certain ends given an explicit amount of resources (inputs) and specific production functions (technologies) in a particular market. In this sense, therefore, economics as a scientific discipline is founded on a utilitarian philosophy of what is universally good (efficiency) and can therefore make claims as to what is a "better" solution, even though the

\footnotetext{
1 "Better" should here be interpreted in the strictly economic sense, i.e. "more efficient [use of resources]." The science of economics is based on the seemingly utilitarian idea that "efficient" is better than "inefficient" because of the greater possibility of satisfaction of consumer wants/demand, and therefore that increases in utility are strictly better than decreases. See e.g. the economics concept "Pareto improvement," which describes a change in which no individual is affected negatively in terms of utility and at least one individual is "better off" (Pareto, 1971). In this sense, economics claims not only to explain and predict economic phenomena but to provide a [normative] basis for decisionmaking.
} 
explicit questions it tries to answer and the phenomena it tries to describe and explain are more scientific in the positive sense.

Economics in general, and especially the Austrian tradition, is deductive in nature and as such guided by a certain set of assumptions of e.g. the rationality of economic actors. Austrian economics consists of a complex set of detailed economic truths derived from the "action axiom," which states that humans take conscious action toward chosen goals. It is wertfrei in that it explains the functions and workings of the market and its institutions, and attempts to explain effects of certain changes in and to the market, such as entrepreneurship and production choices in the first sense and regulations and taxes in the latter.

Just like most other approaches to economics, the Austrian school does not propose or advocate an "ideal" setting or structure for the economic system. On the contrary, it relies significantly less on equilibrium analysis in its study of the market than e.g. mainstream economics. However, Austrian economics rejects statistical methods and empirical studies as means to learn about economic truths and hence adopts a purely deductive approach. As such, it does not refine or change its explanations and theories to "fit" empirical data (as is the case in "semi-deductive" mainstream economic research) and therefore it tends to maintain the truth of fundamental economic theory: that all interventions are necessarily and without exception regarded as causes of inefficiencies or distortions imposed on the economy. ${ }^{2}$ True to form, Block's arguments throughout the book are directly aimed at these causes of inefficiencies: intervention in and regulation of the free market.

It follows from the statement above that the only state of the economy without distorted outcomes and inefficiencies is a market free from interference. Thus, even though Austrian economics is not in itself normative, it clearly shows the strictly negative effects of interventions in the market place, which inevitably provides individuals of certain moral convictions the arguments and moral reasons to espouse an unrestricted market process. There is therefore, to a certain degree, a possible link between the purely scientific study of the market/economy and the normative advocacy of unregulated/free markets.

The normative view supporting free markets as well as, or perhaps primarily, free people is often denoted libertarianism or libertarian ethics. As we have seen, libertarianism is the explicit "vantage point" of Block's study of labor

2 Any and all restrictions of the market process can be shown to cause e.g. inefficiencies through discouraging profitable investments or encouraging "too risky" investments. 
economics, which makes its definition and implications highly relevant to our discussion on a possible violation of Hume's Law. In Block's own words (1994:117, emphasis in original):

"Libertarianism is a political philosophy. It [is] concerned solely with the proper use of force. Its core premise is that it should be illegal to threaten or initiate violence against a person or his property without his permission; force is justified only in defense or retaliation."

This is clearly a prescriptive definition of the political philosophy libertarianism, and as such it should violate the aforementioned law. But this is not necessarily the case. We have already seen that economics as a science and especially its use of the "free market" equilibrium is not perfectly descriptive but includes prescriptive elements; more specifically, economics is the study of the economy using the free market as benchmark. Since libertarian philosophy, using Block's definition above, is concerned only with "the proper use of force" we need only investigate whether this "libertarian law" is compatible with the scientific study of the market.

Any ideology is by definition normative and therefore so is libertarianism. However, as was previously mentioned, it is much less so than competing ideologies in that it insists on a "non aggression principle" as a necessary and sufficient condition of liberty but does not predict nor prescribe the nature of liberty. The principle itself states only that "everyone may act precisely as he pleases, provided, only, that he does not initiate violence against non aggressors" ${ }^{\prime 3}$ (Block, 2008:xix), and is therefore a definition of the necessary limits of freedom (cf. the Hobbesian state of nature in which no such legal limits to freedom exists).

As "libertarian law" states only that people are free to act and associate as they choose for as long as they do not initiate the use of physical force, a number of ideological utopias should be obtainable within that framework and therefore, in a weak sense, compatible with libertarianism. In other words, libertarianism is not exclusive in the sense that it excludes other-thanlibertarian ways of life or organization (cf. Nozick, 1974), and therefore does not make claims for how people should lead their lives. It only limits

\footnotetext{
3 The non-aggression principle is not exclusively libertarian, but is an important part of the so-called "natural law" tradition in which it can be traced back to St. Thomas Aquinas or even Epicurus.
} 
individuals' actions to anything that does not do direct harm to other individuals.

This is very similar to the definition of the free market, where nothing supposedly restricts the competitive market process from bringing the quantity demanded by consumers and the quantity supplied by producers into equilibrium. A market where force exists, i.e. where contracts are breached and property rights violated, would rarely be denoted "free" - the use of force is not compatible with the voluntary exchange of goods and services. As we have already noted, economics, and especially Austrian economics, studies and predicts the negative effects of interventions in the market place. Interventions are any forceful changes to or restrictions of economic actors' behavior, which necessarily includes the initiation of physical force. The free market, therefore, is fundamentally based on a principle that is very similar, or even identical, to libertarian law. Also, libertarianism, based on the non aggression principle, cannot espouse any other economic "system" than a free market economy - all alternative ways of economic organizing would necessarily violate the fundamental principle. The free market and libertarianism are therefore, in substance, two sides of a coin: one cannot exist without [a version of] the other.

But this does not imply that the free market is libertarianism, or vice versa, even though they share fundamental properties both in theory and "practice." The difference lies not in substance, but in use and perspective of the concept. The former is a description of the unrestrained market whereas the latter is an image of a potential "good" society where nothing is allowed to restrict the market (in a broad sense, i.e. including basically any human interaction). Both concepts are therefore identical to the extent that they describe a state of unrestricted voluntary interaction, but different in underlying purpose. It is therefore wrong to claim that the free market is libertarian, whereas it would be correct to claim that libertarianism champions and includes the free market. The perspective and purpose, therefore, while not substance, of the free market concept is primarily positive and scientific, whereas for libertarianism it is normative.

Block is hence correct in that adopting a libertarian point of view in the study of the labor market does not compromise the scientific nature of the economic argument. But only to the extent that his libertarianism does not affect economic conclusions or distort facts and arguments through applying a distinctly libertarian perspective where such is inapplicable; the free market is an economic model of "ideal" (optimal/maximum) efficiency, but libertarianism is not. In other words, the study's scientific value is limited to the extent that the libertarianism in Block's argument is strictly the use of 
the non aggression principle to explain, describe and define the free market. Hume's Law is violated only when and where Block's libertarian views are used in an explicitly normative manner, i.e. when libertarianism is used specifically as a libertarian ethics in addition to the voluntary nature of the free market.

It should therefore be concluded that an "ideological book" such as Block's should not automatically be dismissed as unscientific due to its ideological vantage point. Even though the vocabulary of choice in many of the articles is clearly libertarian, Block generally manages to stay on the right side of the road from a science point of view. His arguments are economically correct and straightforwardly presented; there is no obvious flaw in the logic and he gives the reader no reason to doubt the validity of the argument; economists would find it difficult to criticize Block's strictly economic reasoning. They would first, however, have to see through Block's provocative language and somewhat unorthodox examples.

\section{An Ideological Analysis}

But from a libertarian ideological point of view the author is not as safe from criticism. From a radical libertarian perspective the issues discussed by Block are both interesting and important, but the depth of the analysis of such intervention in the labor market is insufficient - the analysis is too limited and does not take into account all major effects of market regulation. I will here use section II in the book ("Unions") as an example, but the same line of reasoning is applicable on most arguments put forth in the book.

The starting point for Block's analysis is, as has already been discussed at length, the non aggression axiom as a distinguishing property of the free market. In Block's interpretation, the analysis is primarily from a point of view of freedom, a concept which has a distinctly normative flavor. By freedom Block means the rule of libertarian law and therefore non-violation of the non aggression principle - the absence of violence and coercion.

We have already shown that the concept of freedom as a distinctly libertarian ethics is necessarily normative, and that Block's claim to do the analysis from the perspective of freedom would therefore violate Hume's Law. But we have also concluded that the analysis is not in violation of the aforementioned law. The reason for this is that Block does not predominantly provide arguments from a point of view of freedom - despite his claim to do so - but provides arguments distinctly targeted at violent action as interference in the market place. Libertarian freedom might be Block's 
underlying purpose and ideal, but the arguments are above all against certain instances of violent intervention in the market and not pro libertarianism per $s e$. In the analysis of labor unions this fact is made explicit when that which is analyzed is only the coercive aspect of unionism - "we are defining unions as organizations that use coercive force" (Block, 2008:62) - while the noncoercive aspect is disregarded (as is "the other side" of the story: any employer-inflicted coercion of labor workers).

Understood as an argument against the use of violence or physical force, whether or not sanctioned by state laws, the book provides a good overview of the inefficiencies arising due to a number of restrictions imposed on the labor market. In the case of labor unionism Block rightfully goes after the artificial increase in wages brought about through unions' [legal] threats of violence against employers - and the inevitable negative effects thereof. True to the economic analysis, Block argues that "unions cannot raise real wages, only distort them" and that "[u]nions are [...] notorious for undermining management's ability to do its job, which is to increase efficiency" (2008:100).

He also points to the fact that labor unions do not only act in the interest of labor workers against employers, but that there are strong incentives for union leaders, due to their privileged position, to "not only want higher wages for their members" but also "to squeeze every resource of the employer in order to make their union more attractive to prospective dues payers" (2008:103). The coercive labor union therefore distorts the labor market more than a general raise in wage rates would (without an equivalent increase in productivity), through adding incentives that ultimately will force employers to bear costs of union benefits and "marketing."

Even if it were the case that labor unions would act primarily as representatives of labor workers in conflicts with employers, it is argued that "[t]his is a very inefficient and costly way to settle problems which should never exist in the first place" (ibid). These conflicts would not exist in the free market, Block argues, since they arise due to labor unions pushing wages "above the level that a competitive free market would have brought through supply and demand" (2008:99), to which management "must respond by cutting back on production in order to minimize costs" (2008:103).

Block frequently falls back to almost a market equilibrium-based argument, using the free market as benchmark, against the coercive interference in the labor market - labor unions cause distortions through forcing employers to pay higher wages and undermining firm and production management's efforts to increase productivity and efficiency. It is an economic truth that "[w] ages and working conditions aren't set by firms" 
(2008:111) but is determined solely, at least in the long run, by the productivity of each individual person in the market. Block's argument is no doubt firmly based in sound economics; as all economists know, in the competitive free market real wages depend only upon the productivity of labor, which means that the only way of increasing real wages is to increase productivity.

The problem is here that Block seems to partly forget the perspective he claims to have adopted in the analysis: libertarianism. Economists regularly analyze the effects of changes through holding all relevant variables but the one being studied constant; they normally use simplified models in which a single variable can be compared and contrasted with the benchmark equilibrium. Libertarians, on the other hand, guided by a libertarian ethics, would not find a strictly economic analysis satisfactory since it is too limited in scope and therefore would easily fail to notice important but "hidden" aspects and indirect causes of the problem; from a libertarian point of view the existing labor market is so far from being a free market that it is simply impossible to surmise that the distortions are the result only or for the most part of labor unions and union-sponsored, union-supportive regulations.

Murray Rothbard, a leading economist and political theorist in the libertarian tradition as well as in Austrian economics (and frequently cited by Block), has stated that a true libertarian is guided by "a passion for justice" and that such a passion requires "a set of ethical principles of justice and injustice which cannot be provided by utilitarian economics" (Rothbard, 1966:6). With Rothbard, therefore, we must conclude that the Blockian analysis once again falls short of being a manifestly libertarian analysis - it is primarily an economic analysis.

Even though a libertarian analysis would have no problem incorporating Block's conclusions, libertarians guided by a passion for justice would claim there is a much deeper and systemic problem than simply the existence of labor unions and the violence they make use of in the labor market. From a libertarian point of view there is as much of an "injustice" problem on the "other side" of the conflict: employers are not solely victims of unionized, state-sanctioned violence - they are also beneficiaries of a multitude of regulations. They may not normally use direct violent action against hired workers, but they are certainly not perfectly without blame. Corporations and employers enjoy state-sanctioned privileges in the market place just like labor unions. It is simply not the case that unions are villains and employers are not - they are both crooks, but in different ways and perhaps of differing degrees. 
The problem from an economic point of view is here that corporations seem much more regulated at first glance, since labor unions enjoy obvious legal privileges and "labor protection" is explicitly and frequently advocated in political discourse. The common rhetoric used by political decision-makers and interest groups is almost without exception to the benefit of the worker against "powerful" corporations in a hopeless David and Goliath kind of situation. It is therefore easy to assume that regulations are introduced as an attempt to politically strengthen laborers to balance the perceived "market power" of employers.

But regulations are as frequently to the benefit of employers. Regulations raise barriers of entry that protect existing actors in markets; taxes force increases to the working population (which pushes wages down) through making it impossible to afford choosing not to work; government investments in infrastructure and technology act as indirect subsidies to corporations; and the political system provides opportunities for corporations to "buy" their own laws from politicians eager to enrich themselves or gain support for reelection. These are all examples of interventions with direct effect in the labor market, but they are not as easily recognized as union violence. From a radically libertarian perspective they must be deemed at least as important and destructive as the effect of labor unions and union laws; libertarianism does not discriminate between different forms of injustice - all initiation of violence is equally illegitimate and immoral (Rothbard, 1982).

A radically libertarian view could identify a long list of interventions in the labor market that makes it fundamentally unfree and the points on the list would be to the benefit and detriment to literally every actor in the market. Labor unions are to blame for the harm they do, but it is hardly the case that the market would function as a free market were only labor unions and union laws dropped from the equation. The libertarian conclusion would be that even if all the interventions analyzed by Block were removed, the market would still not to a large degree resemble a free market. The violations by or on behalf of firms and employers are absent from Block's analysis of the labor market - it seems to be guided by a one-eyed passion for justice.

To reinstate the free market and its institutions, libertarians would argue that all initiation of violence need be eliminated - systemic, formal, institutionalized and informal alike. And, as Block surely knows, for any market to be truly free it is necessary to abolish government. 


\section{Summarizing Assessment}

Labor Economics from a Free Market Perspective is a provocative book: it is too libertarian to be an economics treatise while too firmly based in economic theory to be a libertarian exposition. As a libertarian anthology it is too limited in scope and "passion" to be a comprehensive investigation of the effects of aggressive violence in the labor markets, and as an economics work it is too polemical and provocative and "ideological" to be taken seriously by mainstream economists. So what is its place in the literature on labor economics?

It is hard to say exactly how to label this book, but it certainly fills a void in the intersection between economic and libertarian theory. In a sense, it proves that economic theory need not be as rigidly positive and lifelessly wertfrei as economists tend to believe - it is possible, and perhaps favorable, for economists to have a strong value-based motivation while carrying out economic scientific studies. Fundamental motivations for research are always and necessarily value-based, which means full disclosure of the scientist's value base would only provide explicit context for understanding, analyzing and criticizing the research - and the reasons for it. By being explicitly libertarian, Block does the reader a favor that economists generally seem determined not to.

This point is even stronger considering chapter 17, where Block recites a statement in support of the minimum wage signed by more than 650 prominent economists including Nobel Prize laureates. Unambiguously, economics shows that minimum wage laws only lead to unemployment and worsening of working conditions; in Block's words, "[e]very Basic Economics 101 textbook [...] make this basic elementary point" (2008:160). The reason for the signatories to support this petition despite the obvious economic truths must therefore be normative - if these economists would have followed Block's example and disclosed their personal value based perspective, their signing of the petition would have been less befuddling. (Of course, the political intent would then be all too obvious.)

Judging from the signatories of the petition, the basic economic truths that Block recapitulates using his characteristically fearless approach and outspoken mode of expression obviously need repeating. And doing so with a distinctly libertarian flavor through explicitly focusing on market interventions as violence is refreshing and thought provoking. Even though it seems unintended, Block manages to prove that economic theory is generally compatible with libertarian political and moral theory without compromising 
with the economic argument - and he shows that economics can indeed provide a strong argument for libertarianism.

\section{References}

Block, Walter. 1976. Defending the Undefendable. New York: Fleet Press. Block, Walter. 1994. "Libertarianism and Libertinism." Journal of Libertarian Studies vol. 11, no. 1 (Fall 1994): 117-126.

Block, Walter. 1999. "Austrian Theorizing: Recalling the Foundations." The Quarterly Journal of Austrian Economics vol. 2, no. 4 (Winter 1999): 21-39.

Block, Walter. 2008. Labor Economics from a Free Market Perspective: Employing the Unemployable. Singapore: World Scientific Publishing Company.

Hoppe, Hans-Hermann. 1993. The Economics and Ethics of Private Property: Studies in Political Economy and Philosophy. Boston: Kluwer.

Hume, David. 1739-1740. A Treatise of Human Nature: Being an Attempt to introduce the experimental Method of Reasoning into Moral Subjects.

Mises, Ludwig von. 1949. Human Action: A Treatise on Economics. New Haven: Yale University.

Nozick, Robert. 1974. Anarchy, State, and Utopia. New York: Basic Books.

Pareto, Vilfredo. 1971. Manual of Political Economy. Translated by Ann S. Schwier. Edited by Ann S. Schwier and Alfred N. Page. New York: A. M. Kelley.

Rothbard, Murray N. 1962. Man, Economy, and State: A Treatise on Economic Principles. Princeton, N.J.: Van Nostrand.

Rothbard, Murray N. 1966. "Why Be Libertarian?" Left \& Right: A Journal of Libertarian Thought vol. 2, no. 3: 5-10.

Rothbard, Murray N. 1982. The Ethics of Liberty. Atlantic Highlands: Humanities Press. 